\title{
Using geoarchaeological deposit modelling as a framework for archaeological evaluation and mitigation in alluvial environments
}

Chris Carey, School of Science and Environment, Cockcroft Building, University of Brighton. BN2 4GJ.

Andy J. Howard, Department of Archaeology, University of Durham, South Road, Durham, DH1 3LE.

Robin Jackson, Archive and Archaeology Service, Worcestershire County Council, The Hive, Sawmill Walk, The Butts, Worcester, WR1 3PB, UK

Antony Brown, Palaeoenvironmental Research Laboratory, Geography and Environment, University of Southampton, Highfield Campus, Southampton, SO17 1BJ

\begin{abstract}
The pace of anthropogenic development on floodplains and adjacent valley floors is still increasing and in many countries this is accompanied by a requirement for heritage mitigation and management. The result is an increased demand for effective and efficient archaeological evaluation and mitigation strategies, which can only be achieved in alluvial environments through the application of geoarchaeological methods. This paper uses lidar data combined with deep geophysical survey (electrical resistivity), gouge coring and limited borehole data to derive a three dimensional geoarchaeological deposit model, which provided a vehicle for archaeological evaluation and mitigation. Significantly, the results of this deposit model are compared to the results from the subsequent archaeological evaluation trenching, a methodological next step that has not received sufficient attention within the (geo)archaeological literature. The deposit model is refined using radiocarbon dating and artefactual evidence derived from the archaeological evaluation trenching. The results demonstrate how geoarchaeological deposit modelling can be integrated with archaeological evaluation trenching and provides discussion of the importance and difficulties of integrating geoarchaeological sediment units (archives) with archaeological contextual excavation data, with conventional stratigraphic matrices.
\end{abstract}

Keywords: Alluvial geoarchaeology, archaeological evaluation, deposit modelling, chronostratigraphy 


\section{Introduction}

The ability to understand, predict or model the distribution of archaeological remains, whether landscape or site based, is a key concern for all sectors of the heritage community (e.g. Hey and Lacey 2001; Fry et al. 2004; Howard et al. 2015; Demján and Dresklerová 2016), and is critical for practitioners and their funders ahead of major infrastructure projects. The capacity to detect archaeological sites located within geologically and geomorphologically simple terrain units such as calcareous bedrocks, the classic dryland context, has undergone wide-scale development during the twentieth century using a variety of prospection techniques such as aerial photography (e.g. St Joseph, 1977; Barber, 2011), and more recently airborne remote sensing technologies (Challis and Howard 2006; Ninfo et. al 2009; Rowlands and Sarris 2007; Parcak 2009). These airborne techniques have been complemented by the development of ground-based geophysical survey methods, primarily gradiometer survey, earth resistance survey (Aitken 1958; Gaffney 2008; David et. al 2008) and ground-penetrating radar (Conyers 2004; Herrman 2013). Such techniques have revealed a wealth of archaeological resources demonstrating the rich nature of the historic environment record.

Alongside this increasing knowledge of site detection and identification, there has been a growing realisation of the importance of understanding geomorphological processes, landform assemblages and four dimensional stratigraphic architecture to facilitate the interpretation of archaeological distributions and preservation potential (Howard and Macklin, 1999; Howard et al. (eds) 2003; Brown, 2008; Arnaud-Fasetta and Carcaud, 2014). The topography and resources of alluvial palaeolandscapes exert a significant, but not yet fully understood, influence on past societal choices and opportunities; therefore, mapping and understanding landform assemblages such as palaeochannels and river terraces can offer insights into the distribution of archaeological remains (Passmore et al., 2006; Ayala et al. 2007; Mozzi 2012) and facilitate resource-based modelling (Brown et al. 2013a).

Critically, geomorphological processes and complexity can dictate the visibility of archaeological sites to conventional methods of archaeological prospection, through factors such as erosion, sedimentation and burial (Howard et al. 2008). However, established methods for mapping archaeological remains, such as aerial photography and magnetic gradiometer survey, are shallow prospection techniques and will not penetrate sediment depths of >1m (Clark 1990; Gaffney and Gaiter 2003). The use of these techniques to map shallow buried archaeological structures and features is followed by evaluation trenching, used to ground truth results and recover datable material. However, where archaeology is stratified within deeper sedimentary sequences $(>1 \mathrm{~m})$, detection is more problematic (Bates and Bates 2000). Such sediment sequences render archaeological remains undetectable to these conventional methods of archaeological prospection 
such as gradiometer survey, fieldwalking, aerial photography and shallow test pitting (Macklin et al. 1992; Passmore et al. 2002). Therefore, these vertically accreted sediment environments require the use of geoarchaeological deposit modelling (see section 2.2) to understand sediment architectures and depositional environments, which in turn, can be related to archaeological potential (e.g. Chapman et al. 2009).

To plan effectively for the mitigation of impacts to historic environmental resources, baseline knowledge of the richness and complexity of the archaeological resource within an area is fundamental (Chapman, 2006, 10), which must utilise methods tailored to the specific circumstances of the environment in question. In terms of alluvial environments, this can be conceptualised as an idealised typical temperate river valley (Figure 1), where the archaeological and palaeoenvironmental potential is intimately linked to geomorphological processes, which in turn, dictates the methods suitable for revealing the historic environmental resources and planning suitable investigation strategies. In alluvial landscapes, geoarchaeology should be seen as the vehicle for the design and implementation of any overarching historic environment mitigation programme, providing understanding of the sediment chronology, the depositional environment and the archaeological and palaeoenvironmental resources.

\section{Geoarchaeological deposit models and archaeological predictive models}

It is important to make a distinction between archaeological predictive modelling (sensu Espa, et al. 2006) and geoarchaeological deposit modelling, also called geoarchaeological predictive modelling, (sensu Bates and Bates et al. 2000). This terminology is significant as it reflects a substantive difference in approaches to understanding and mitigating impacts to historic environmental resources, and it differs fundamentally in the currency of the data each approach employs.

\subsection{Archaeological Predictive Modelling}

Archaeological predictive archaeological principally derives from studies in America and northwestern Europe (Verhagen and Whiteley 2012, 49-50) where it has been used to model, identify and define archaeological distributions (patterns) across the contemporary surfaces of landscapes, using both inductive and deductive approaches (Kamermans and Wansleeben 1999). The predictive archaeological model has at its centre a "desire to understand archaeological site locations in a region on the basis of observed patterns, or, an assumption of human behaviour" (Ibid, 225). Such models 
once constructed are statistically tested to assess their reliability, against a known archaeological distribution in that landscape to assess the models performance, although there has been debate about the reliability and suitability of applying such models to complex archaeological landscapes (Kamermans 2010).

Critically, such predictive models are based on observed attributes of the current physical landscape recorded at the contemporary surface. For example, Verhagen and Drăguţ (2012) used Object Based Image Analysis of a DEM from lidar data ( $5 \mathrm{~m} \times 5 \mathrm{~m}$ posting) to create a landscape geomorphometric classification model to use within an archaeological predictive model; Vaughn and Crawford (2009) used key environmental variables defined from contemporary remotely-sensed data (e.g. vegetation colour and topography/slope) to predictively model Maya settlement in northwest Belize, whilst Rua (2009) attempted to identify potential locations of rural Roman villae in Portugal using a range of topographic, hydrological and slope variables.

These models have had some success in identifying the distribution of archaeological sites across landscapes, especially for hunter gatherer societies (e.g. Jochim 1976). A key issue for archaeological predictive models is the transfer function of such modern phenomena as having been caused by, or influencing, human activity in the past, and whether these modern environmental variables such as soil type, precipitation and topography were the same in the past, with a lack of temporal data within such predictive models noted as a key challenge (Ebert 2006). These environmental factors can be viewed as drivers for cognitive processes in past individuals and societies, who selected specific 'locales' to become areas of human activity, which subsequently became transformed into an archaeological sites (see Brown et al. 2013a).

Whilst such assumptions might be implicit or explicit in the use of these models, they assume a geomorphologically simple environment and uniform site visibility. Whilst landscape probability maps routinely include different geomorphological environments such as wetlands, rivers, elevated terraces, etc, they do not consider the deeper sediment stratigraphy and architecture of the subsurface environment. Verhagen and Tol (2004) and Verhagen et al. 2013 did attempt to incorporate predictive modelling elements within a sub-surface survey, but in this example the density of artefact recovery was discussed and not related to the sub-surface sediment architecture and topography. These approaches of archaeological predictive modelling contrast to the approaches developed for geoarchaeological deposit modelling described below.

\subsection{Geoarchaeological Deposit Modelling}


Within geoarchaeological deposit models the dynamic nature of sediment deposition/erosion is considered the fundamental issue for both urban (Neal 2014) and non-urban environments (Hijma et al. 2009). In this sense the current landscape cannot be used as an analogue for the past, as the landscapes from previous periods are buried under the modern topography and hidden from view: they cannot only be recorded from the surface and require a mixture of surface survey combined with intrusive data collection. Hence, a geoarchaeological deposit model will combine sub-surface investigations of sediment architectures with surface collected data relating to topography and superficial geology to produce pseudo 3D reconstructions of sedimentary sequences (Passmore et al. 2002).

These buried landscapes are revealed through geoarchaeological deposit modelling, using a combination of invasive techniques, such as boreholes and cone penetration testing, and non-invasive techniques, primarily ground penetrating radar, electromagnetic techniques, gamma-cps, resistance penetrometry, seismics, electrical resistivity tomography and the recording of exposed sediment sections along river banks and quarry faces. These methods are employed to understand archaeological potential in relation to sedimentary architecture and geomorphological processes (Bates et al. 2007; Koster 2016; Verhegge et al. 2016). Through understanding the sediment structure of such buried landscapes and sitescapes, it is possible to identify buried land-surfaces, episodes of sediment deposition and erosion, and relate sediment architecture to specific environments of deposition.

Unlike predictive archaeological modelling, geoarchaeological deposit modelling does not attempt to predict where precisely within a landscape/sitescape these archaeological sites/remains might occur, but instead seeks to define an archaeological potential for a landform assemblage, for example, a Pleistocene terrace, palaeochannel, etc, to contain cultural or environmental archaeological remains. Within geoarchaeological deposit modelling the understanding of geomorphological complexity is key, as it dictates the visibility of historic environmental resources to conventional methods of archaeological prospection, and as described above, many of the standard archaeological prospection techniques are ineffective within deeply stratified sequences. Consequently, the distribution of archaeological resources contained within deep sediment sequences cannot be understood through surface based survey and require intrusive data capture to define sub-surface sediment architectures.

Most geoarchaeological deposit models will initially be both multi-period and based upon sediment stratigraphy as at this stage there will be limited (if any) available dating, except for a division between Pleistocene and Holocene sediments. Most dating is subsequently recovered through the archaeological site-based excavation work, with geoarchaeological deposit modelling preceding 
ground-based archaeological programmes. The introduction of chronological data into deposit models provides refinement to them, identifying and often constraining the timing of formation of different landscape components such as palaeochannels and key lithostratigraphic units.

\section{Application of geoarchaeological deposit modelling}

Over the last decade within the UK, there have been considerable advances in the design of archaeological mitigation strategies incorporating geoarchaeological deposit modelling, which are sympathetic to geomorphological complexity (e.g. Sidell et. al 2000). Archaeological mitigation here is used to denote the identification, excavation and retrieval of archaeological remains within a developer-funded context. An important catalyst for this advancement of methodological approaches was the now discontinued Aggregates Levy Sustainability Fund (Brown 2011), a scheme, in part administered by Historic England that played a significant role integrating academic research with the more immediate and practical needs of commercial archaeologists.

Geoarchaeological studies have been undertaken on a number of geomorphologically contrasting river systems, including the Severn (Jackson et. al. 2013), Trent (Knight and Howard, 2004), Till-Tweed (Passmore and Waddington, 2009) the Nene (Allen et al. 2009), Swale Ure (Bridgland et. al 2011), Axe (Brown et al. 2014) and Thames (Bates and Stafford 2013). This melding of academic research thinking and commercial sector ground based application is highly desirable, as each group brings specific skills and experiences to mitigation design and landscape understanding. It also encourages geoarchaeological development and innovation in allied techniques, such as chronology and dating (Duller 2008; Toms et al. 2011), terrestrial geophysics (Carey et al. 2007) and modelling (Van De Weil et al. 2011).

However, whilst there has been increasing use of geoarchaeological deposit modelling, there has been little published on the integration with archaeological excavation methods, creating a gap in understanding of the successes and limitations of such geoarchaeological deposit models in defining archaeological potential. For example, a recent review of scientific advances within geoarchaeology did not explicitly mention deposit modelling (Canti and Huisman 2015); this reflects the fact that even though deposit modelling is one of the most commonly applied geoarchaeological methods at the commercial/academic interface, the results of such work and archaeological validation are rarely published within peer-reviewed literature. Previous research on the success of archaeological evaluation trenching strategies has focused on examining the trenching design based on their size and distribution (Hey and Lacey 2001; Verhagen and Borsboom 2009), with little attention paid to the 
differences in geomorphological environments and how these might affect the visibility and detection of archaeological resources.

Critically, within alluvial systems it is essential to understand the depositional environment, in respect of the chronology of both erosion and sedimentation, facilitating identification of geomorphological zones or components, which in turn, define evaluation strategy for both cultural and environmental remains. Somewhat surprisingly, although numerous studies have described geoarchaeological assessments of alluvial/wider landscape environments, relatively few have tested the emergent predictive models against evaluation excavation. This paper provides an example from the Lugg valley, Herefordshire (UK) where a geoarchaeological deposit model was tested against the results of archaeological evaluation. These results are used to facilitate wider discussion of the application of deposit modelling as a framework for mitigating impacts to historic environmental resources. Although the example outlined here is UK based, the principles are applicable within any planning framework that is attempting to mitigate impacts on the historic environment within a temperate alluvial environment and it has close parallels with alluvial geoarchaeology along major European rivers such as the Seine (Pastre et al. 2014), the Loire (Castanet et al. 2014) and the Po (Marchetti 2002).

\section{The Lugg Valley geoarchaeological context}

The River Lugg is a major tributary of the River Wye, rising in the Welsh borderland near Presteigne and joining the latter at Mordiford Bridge (NGR: 356520, 237160), approximately 15km downstream of Hereford. South of Hope under Dinmore in the vicinity of Wellington Quarry, the valley floor forms a relatively wide basin, underlain by Old Red Sandstone of Devonian age (Figure 2). The Lugg has a complex drainage history predating the last glaciation, as demonstrated by the suite of four fragmentary gravel terraces that lie beyond the Devensian ice limits (Brandon, 1989). During the Holocene, fine-grained alluviation has characterised the river system, blanketing the Late Pleistocene sands and gravels or lapping against the margins of more expansive remnants of terrace and gravel islands (Brown et al. 2005).

These higher, drier areas have provided the foci for settlement since the Upper Palaeolithic and been subject to archaeological investigations in advance of quarrying over the past 30 years, yielding significant evidence for human activities from the Neolithic through to the medieval period (Bapty 2008; Jackson and Miller, 2011). Prior to this study, previous geoarchaeological investigations at Wellington Quarry had identified a number of episodes of prehistoric and Roman minerogenic 
alluviation (Dinn and Roseff, 1992), which have subsequently been divided into a tripartite sediment sequence (Jackson and Miller, 2011).

\section{Constructing the geoarchaeological deposit model}

The proposed extension of the aggregates quarry by 45 Hectares and associated evaluations in 20078 afforded an opportunity to develop a geoarchaeological deposit model for the development area and to use this as a vehicle for informing the archaeological evaluation strategy. The geoarchaeological deposit model was created within a GIS (ARC ver 9.3), utilising a range of desk and field-based data sources to provide a three-dimensional conceptual framework. British Geological Survey (BGS) mapping of superficial and solid geologies (1:50,000 scale) was combined with Ordnance Survey 1:10,000 sheets, previous borehole records, archaeological data (provided by Herefordshire Historic Environmental Record) and topographic data from lidar (supplied by the Environment Agency). The lidar data identified significant topographic variation within the floodplain, which had previously been mapped as a homogeneous parcel of minerogenic alluvium by the BGS. Several large palaeochannels were clearly visible, with two of these extending the mapping of features recorded during earlier excavations (Jackson and Miller 2011; Figure 3); the topographic variation in the floodplain could be divided into two topographically distinct components. Borehole records indicated that the three key minerogenic alluvial units, previously described by Jackson and Miller (2011) continued into the study area:

Unit 1: Stiff, red brown silty clay. This unit has previously been recorded sealing later prehistoric, Romano-British and early medieval archaeology, indicating a mid to late Holocene date of formation.

Unit 2: Yellow-brown clay silt. This unit has previously been shown to contain archaeology from the Mesolithic through to the Romano-British period, demonstrating an extended period of formation during the Holocene.

Unit 3: Red brown silty clay, with abundant sub-rounded clasts. This unit has an irregular gradational base and directly overlies the sands and gravels; it is interpreted as a weathering profile developed towards the end of the Late Pleistocene and may be a correlative of the late glacial 'soil' described by Brown et al. (2005).

The palaeochannels and floodplain components identified from the lidar (Figure 3) were investigated by Electrical Resistivity (ER) survey in combination with gouge coring, to elucidate the sub-surface 
sediment architecture. Electrical resistivity survey was undertaken using an IRIS Syscal Junior 48 electrode system with inbuilt switching unit using a $1 \mathrm{~m}$ electrode spacing, with the position of the survey transects within the study area mapped using differential GPS (Figure 3). An example of the results is given as transect 3 , which defined a palaeochannel that bisects an area of floodplain (Figures 4 and 5). The palaeochannel contained five blue-grey, minerogenic silt-clay fills. The tripartite division in alluvial stratigraphy previously described is evident, with sediment units $1,2 a, 2 b$ and 3 definable in both the gouge core and electrical resistivity transects. The dissociation of units $2 \mathrm{a}$ and $2 \mathrm{~b}$ was identified via the gouge core stratigraphy, indicating variability in clay/silt content between the upper and lowers parts of this sediment unit. The palaeochannel revealed a number of discrete fills (e.g. Fills 2, 3 and 5; Figure 5), some of which contained a high potential for organic preservation and palaeoenvironmental analysis.

\section{The geoarchaeological deposit model}

By combining these data a deposit model of sub-surface sediment architecture and archaeological potential was constructed, which informed the archaeological evaluation trenching strategy. The deposit model was constructed to have an integral chronological dimension, but as this model was formed prior to evaluation trenching, this chronology was only tested subsequently by radiocarbon dating of samples from excavated deposits. The sequence of landform evolution is derived from the lidar topography with the capacity of the model increased through the addition of sub-surface sediment stratigraphic data. This facilitated construction of a three-dimensional chronostratigraphic framework for the development area, providing age estimates for each geomorphological component, which in turn, provided an indication of sediment type and preservation potential.

On the basis of these data the deposit model divided the development area into a series of landform assemblage components (Table 1; Figure 6):

- Higher Floodplain Component H2: An area of topographically higher floodplain.

- Lower Floodplain Component H1: An area of topographically lower floodplain.

- Palaeochannel 1: West side of the study area and bisects Lower Floodplain Component H1.

- Palaeochannel 2: Boundary between the Higher Floodplain Component $\mathrm{H} 2$ and Lower Floodplain Component H1.

- Palaeochannel 3: Bisects Higher Floodplain Component H2.

- Palaeochannel 4: A meander from the contemporary floodplain (outside the revised development area). 
The Higher Floodplain Component $\mathrm{H} 2$ was underlain by sands and gravels, which in this case study example were deposited during the late Pleistocene (late Devensian). These coarse grained sediments were overlain by two main fine-grained minerogenic units, one yellow silt dominated and the other red clay dominated; interpreted as the correlative equivalent of Units 1 and 2. Given this stratigraphy, the Higher Floodplain Component $\mathrm{H} 2$ had the potential to contain archaeological remains from the Mesolithic through to the Post-Medieval periods. The gouge core/resistivity transects demonstrated that Palaeochannel 3 bisected Higher Floodplain Component $\mathrm{H} 2$.

Fluvial incision and erosion in the late Devensian and early postglacial period was interpreted as responsible for the formation of the topographically Lower Floodplain Component H1. Borehole and gouge core data demonstrated that basal sediments of Lower Floodplain Component H1 comprised sands and gravels, but these again were overlain by Units 1 and 2, but also Unit 3, indicating a period of alluviation from the early Holocene onwards. The sediments associated with $\mathrm{H} 1$ and $\mathrm{H} 2$ are of similar depth and composition suggesting they were affected by comparable formation processes; however, given the lower topographic position of Lower Floodplain Component $\mathrm{H} 1$ and likelihood of increased waterlogging associated with fluctuating groundwater tables and periodic overbank flooding throughout the Holocene, the deposit model suggested a lower archaeological potential due to unsuitability for settlement from the early Holocene.

The date of Palaeochannel 1 could not be estimated from the deposit model, although by its relative position, it must post-date Lower Floodplain Component H1. During gouge coring Palaeochannel 2 was shown to contain peat deposits and minerogenic fills interpreted as mid-Holocene or later, based on relative topographic position rather than palaeoecological evidence or radiometric dating. Gouge coring demonstrated that Palaeochannel 3 had a sand/silt dominated fill and this sequence was interpreted to be of late Devensian/early Holocene date, due to its elevated topographic position, coarse grain size and inorganic nature. At an undefined point in the later Holocene, the contemporary channel of the River Lugg was occupied and Palaeochannel 4 represents an abandoned meander from this period. The general model for the development area is summarised in Table 1 and Figure 6.

\section{Evaluation trenching}

The geoarchaeological deposit model informed the evaluation trenching design, which consisted of 43 trenches investigating the different floodplain components, with the sampling level dependant on the archaeological potential described by the deposit model (Figure 6). Some flexibility was retained in the trenching design to be able to extend trenches that encountered areas of archaeological 
remains, but the general trench size was $2 \mathrm{~m} \times 50 \mathrm{~m}$. The palaeochannels were investigated with trenches that traversed these features and extended onto the adjacent floodplain components. These trenches provided a sample of approximately $1 \%$ (by area) of the palaeochannels, identifying a high palaeoenvironmental potential, but a lower potential for significant in-situ archaeological remains. This trenching design provided cross-sections of the valley floor; enabling environmental sampling of organic palaeochannel fills, whilst investigating the relationship between the palaeochannels and the wider floodplain. The two floodplain components were investigated at slightly different resolutions: a $2 \%$ (by area) trenching sample was applied to the Lower Floodplain Component $\mathrm{H} 1$ since it was anticipated to have a lower archaeological potential; in comparison the Upper Floodplain Component $\mathrm{H} 2$ had a 3\% (by area) trenching sample, due to its modelled higher archaeological potential.

Archaeological remains and features were widely discovered across the excavation trenches, with archaeology such as pits, postholes and ditches present (mainly prehistoric; Figures $7-9$ ). The excavation trenches also revealed multiple palaeochannel incisions (labelled through denoting the palaeochannel number, e.g. 2 and then fill number as a roman numeral, e.g. Palaeochannel 2i, 3v, etc) within sediment sequences containing palaeoenvironmental archives. The distribution of the cultural deposits and features were consistent with the deposit model and where possible were dated using a combination of radiocarbon dating and by reference to artefactual and stratigraphic evidence. Where dating evidence was not obtainable, the location of deposits and features and their relationship to the tripartite alluvial sequence was reviewed to provide broad age estimates, with a key indicator being the colour of the fills of features (Figure 8). No artefactual remains were found within the palaeochannels.

A strong correlation existed between the survival of moderate to well-preserved palaeoenvironmental deposits within the palaeochannels as described by the deposit model, as Palaeochannels 1 and 2 both included organic peaty deposits and had a high potential for palaeoenvironmental reconstruction. In contrast, Palaeochannel 3 contained up to six re-incisions, but the fills were generally of a coarser particle size (sand and silts) and preserved no datable organic material. The palaeochannels proved considerably complex, with numerous abandonments, incisions and reactivations recorded, especially within Palaeochannels 2 and 3 (Figure 10). In addition to the tripartite alluvial sequence, an organic unit was found within Palaeochannel 3, labelled as Unit 5, which represented a stasis layer between periods of channel activity. Unit 5 was also found in Trench 21 separating alluvial Units 1 and 2. Samples for radiocarbon dating were selected with particular reference to a number of 'key' events including this organic 'stasis' layer (Unit 5), a Neolithic pit, cremation deposit (ceramically dated to 
the Bronze Age), elements of palaeochannel sequences and a well-preserved pollen sequence from Palaeochannel 1.

A strong correlation was demonstrated between significant archaeological deposits and Higher Floodplain Component H2. The archaeological remains comprised dispersed, but localised areas of highly significant prehistoric activity. Such archaeological remains included in-situ prehistoric features, e.g. pits, postholes; in-situ isolated finds within Unit 2, and also residual prehistoric artefacts, (Figure 7). This archaeology included Neolithic and Beaker pits of which feature [2710], in Trench 27 produced 99 flints, as well as a polished stone axe fragment (Figure 9). Another significant find was a Bronze Age cremation cemetery in Trench 15, with a series of 21 pits, one containing a cremation in a Deverell Rimbury urn and a second pit containing a further un-urned cremation deposit.

Significantly, as the distribution of archaeology demonstrates, nearly all of the prehistoric activity was on the Higher Floodplain Component $\mathrm{H} 2$ (with the exception of two small undated, but probable prehistoric features in Trench 7). Also significant is that all of the prehistoric archaeology was associated with Unit 2, either buried by, or cutting this key alluvial stratigraphic unit. Only a limited range of archaeological features were present across the Lower Floodplain Component H1; associated remains were of probable Roman or later date and were restricted to water management features, drainage and boundary ditches (Figure 8). No earlier prehistoric deposits were identified within the area of this Lower Floodplain Component $\mathrm{H} 1$ (with the exception of Trench 7, as above). The lidar mapping of this lower Floodplain Component $\mathrm{H} 1$ has extended the known distribution of a previously identified historical water meadow system. Full archaeological mitigation of the development area has yet to occur, but this will provide a further window of opportunity in comparing the geoarchaeological deposit model and evaluation trenching with a full analysis of the archaeological deposits across the study area.

\section{Chronological evolution and wider implications}

The post-excavation analysis provided eight radiocarbon dates for key stratigraphic parts of the sediment sequence and associated archaeological deposits (Table 2, Figure 11). The dating of these key elements largely vindicated the initial deposit model predicted chronology of the geomorphological components (column 3) and the absolute dates (columns 6 and 7). An overview of the relationship between the major alluvial sediments, key geomorphological features and significant phases of archaeology is illustrated as a schematic matrix (Figure 11) and this can be related to the geoarchaeological deposit model, through the main sediment units illustrated as coloured blocks within the matrix. 
The application of radiocarbon dating provides an understanding of the timescale of formation of the palaeolandscape and when combined with environmental analyses can be used to elucidate environmental conditions at different points during the Holocene. It is worth emphasising that this dating resolution was obtained during the evaluation excavation phase, as it was the moment that larger exposures of the sediment sequence were revealed interleaved with archaeological deposits. The recovered archaeological materials, such as pottery, provided additional dating evidence in their own right, augmenting the evidence provided by radiocarbon dating of macro-organic remains from secure archaeological contexts.

Whilst the presentation of such a schematic matrix from this study is unusual for geomorphologists, geoarchaeologists and archaeologists (Figure 11), it provides a potential unification of the sediment architectures described by the geoarchaeological deposit model and the archaeological remains discovered through excavation, normally represented through a Harris Matrix. This schematic matrix is represented in two dimensional space, but it represents a three dimensional sedimentary landscape that has evolved over time, a fourth dimension (cf. Brown 2008). This fourth dimension is not unidirectional and represents a significant obstacle for integrating archaeological and geoarchaeological recording systems.

Archaeological remains are recorded through contexts in archaeological excavations, and each represents an event in time, which are combined to create a narrative of past human activities. Contrastingly, the widespread alluvial sediment units described by the deposit model represent multiple depositional and erosional events, having a longevity in their formation with a chronological dimensions that can work on spatial $X$ and $Y$ axes, as well the $Z$ (vertical axis). Although Unit 2 is known to be prehistoric, in one part of the development area this could reflect a Neolithic date, whilst elsewhere in the valley floor it could be an Iron Age or Bronze Age date. Therefore, when two discrete archaeological features are contained within Unit 2 they can be radically different ages, although in a two dimensional stratigraphic relationship they are contained within the same sediment unit. The presentation of the matrix allows the evolution of the sediment units to be viewed with human events (contexts) occurring within the timeframe of deposition of these sediments.

This longevity of formation of these widespread sediment units, as opposed to much shorter lived archaeological contextual events, is a significant problem for integrating these two facets of the same investigation. There is an archaeological requirement to produce more complex 3D archaeological stratigraphic matrices that can cope with this chronological complexity of widespread vertically or laterally accreting sediment units and the archaeological deposits they contain. Within simple dryland archaeological contexts on bedrock, such potential chronological conflicts are difficult to recognise, 
due to relatively static and homogeneous geological conditions into which the archaeological features are cut, e.g. ditches, or are placed on top of, e.g. banks. Contrastingly, in complex vertically and horizontally accreting depositional environments such as described in this model, there are multiple topographic templates (or land-surfaces) that are contained within the sediment archives, which can have formed during both the Pleistocene as well the Holocene.

The geoarchaeological deposit model also sheds light on the mechanisms and rates of change in the alluvial environment, which can have implications for human groups. The preservation of archaeological remains on the Higher Floodplain Component $\mathrm{H} 2$ and the presence of three linear palaeochannels with internal evidence for multiple reactivations indicates a system of channel change driven by rapid switches of course (avulsion), rather than lateral migration. Channel evolution by avulsion has also been recorded in the Middle Trent around Lockington in a highly sinuous channel belt (Brown et al., 2013c), suggesting that avulsion as a mechanism of channel change may be more widespread than previously considered (e.g. Tornquist, 1994); such a conclusion has significant implications for the preservation potential of archaeological remains more generally.

The widespread and mappable character of the three main alluvial units across this development area has been identified in other parts of the wider Lugg valley floor, and this has further significance. The nature of this tripartite stratigraphy indicates continuity and longevity in sedimentation within the catchment, and potentially provides a window of opportunity in accessing information on wider aspects of human-environment interactions and processes of sediment supply. Similar patterns of alluvial deposition have been recorded in lowland rivers across the UK such as the River Frome, Herefordshire (Brown et. al. 2013b) and valleys in the East Midlands (Smith et al. 2005), as well as valleys in many areas of coastal Europe (Hoffman et al. 2010). Further geoarchaeological analysis is being undertaken on the alluvial sequence at Wellington Quarry, but if chronological continuity can be applied to the formation of these key stratigraphic units, then wider factors such as climate variability and land-use narratives can be investigated through these fluvial archives. Integration of the Lugg sequences with work from the Rivers Arrow, Frome and Wye within adjacent catchments of the West Midlands has the potential to allow development of inter-regional valley geochronologies and to input into national and international debates concerning the stratigraphic signal of the Anthropocene (Gales and Hoare, 2012; Lewin and Macklin, 2014). The results of this ongoing work also provide a basis and opportunity for beginning to compare the geoarchaeological records and preservation potential of lowland river systems with those of the piedmont and upland zone, which have different late Pleistocene and Holocene evolutionary histories (Howard and Macklin, 1999). 


\section{Conclusion}

The application of geoarchaeological deposit modelling within archaeological investigation programmes has the capacity to provide significant benefits in understanding geomorphological complexity and the distribution and preservation of archaeological resources. Instead of predetermined evaluation strategies based on a percentage of development area (typically $5 \%$ of the affected area is assessed in archaeological evaluation within the UK), a targeted evaluation strategy should be developed commensurate with the archaeological potential of defined geomorphological units and landform assemblages. Such targeted evaluation trenching approaches can reduce the cost of the overall evaluation, both in terms of time and money, and test the character of the archaeology in areas of high potential, rather than identify the presence or absence of archaeological remains. In the case of the Lugg, even in areas of highest potential this did not exceed $3 \%$ by area of the Higher Floodplain Component $\mathrm{H} 2$.

Such deposit modelling strategies provide a clear framework within which to undertake archaeological evaluation and mitigation. The approach highlights the value of using a geoarchaeological framework at the start of the mitigation process, as the vehicle for all future archaeological investigations. Within the archaeological literature there is a lack of studies describing the results of geoarchaeological deposit models and testing these models against archaeological excavation. With increasingly advanced methods of remote sensing, geoprospection and sub-surface modelling occurring within geoarchaeology and being applied within deposit modelling contexts, there is a need to test the emergent properties of these models against archaeological reality. The full-scale archaeological mitigation on this study area of the Lugg valley is yet to occur, but when it does happen, it will create a further significant body of information to contribute to this debate.

By undertaking such geoarchaeological deposit modelling there is a better understanding of archaeological resources and deposits within complex landscapes, producing more refined archaeological products. Firstly, there is a greater appreciation of pathways, opportunities and exploitation of landscapes in the past achieved by understanding geomorphological evolution and palaeolandscape development. Secondly, there is a greater ability to integrate geoarchaeological, palaeoenvironmental and archaeological sampling and investigation, all leading to improved narratives of the human past, although as discussed, research has to be directed at tackling the challenge of true three-dimensional stratigraphic complexity. Lastly, there is an enhanced ability for cultural resource management. With large trans-landscape infrastructure projects on the horizon across the globe, such High Speed 2 and 3 in the UK, the extension of the TGV/LGV in France and the Maglev super-speed trainline in Japan, there is an imperative to provide frameworks sympathetic to 
variability of archaeological resources, within widely differing geomorphological environments, allowing selection of the best archaeological techniques in different landscape settings.

\section{Acknowledgements}

This work was funded by Tarmac Trading Limited in advance of quarrying activity and thanks must go to Malcolm Lawer (Estates Manager), Rowan Elliott (Area Manager) and Jim Whitney (Quarry Manager) who supported the project throughout. Additional thanks must go to Dr Keith Ray (formerly County Archaeologist) and Julian Cotton (Archaeological Advisor) from Herefordshire Council, who as Curators, supported the design and implementation of the project. Finally, thanks must go to Simon Sworn (Project officer) of Worcestershire Archaeology who led the fieldwork at Wellington. 


\section{References}

Aitken, M. J. 1958. Magnetic prospecting: the Water Newton survey. Archaeometry, 1, 24-29.

Allen, P. and Brown, A.G. 2009. Synthetic Survey of the Environmental Archaeological and Hydrological record for the River Nene from its source to Peterborough. Report for English Heritage. Exeter University: Exeter.

Arnaud-Fassetta, G. and Carcaud, N. (Eds.) 2014. French Geoarchaeology in the $21^{\text {st }}$ Century. CNRS Editions, Paris.

Ayala, G., Canti, M., Heathcote, J., Sidell, J. and Usai, R. 2007. Geoarchaeology: using earth sciences to understand the archaeological record. English Heritage: Swindon.

Bapty, I, 2008 Lower Lugg Floodplain Archaeological Mitigation Review, Hereford: Herefordshire Archaeology Report, 243. Hereford.

Barber, M. 2011. A History of Aerial Photography and Archaeology: Mata Hari's Glass Eye and Other Stories. English Heritage: Swindon.

Bates, M. and Stafford, E. 2013. Thames Holocene: A geoarchaeological approach to the investigation of the river floodplain for High Speed 1, 1994-2003. Oxford Wessex Archaeology monograph, Oxbow: Oxford.

Bates, M. R., Bates, C. and Whittaker, J. E. 2007. Mixed method approaches to the investigation and mapping of buried Quaternary deposits: examples from southern England. Archaeological Prospection, 14, $104-129$.

Bates, M. R. and Bates, C. R. 2000. Multidisciplinary approaches to geoarchaeological evaluation of deeply stratified sedimentary sequences: examples from Pleistocene and Holocene deposits in Southern England, United Kingdom. Journal of Archaeological Science, 27, 845 - 858.

Brandon, A. 1989. Geology of the country between Hereford and Leominster. Memoir for 1:50,000 geological sheet 198 (England and Wales). London: HMSO.

Bridgland, D., Innes, J., Long, A. and Mitchell, W. 2011. Late Quaternary Landscape Evolution of the Swale-Ure Washlands, North Yorkshire. Oxbow Books: Oxford.

Brown, A. G. 2008. Geoarchaeology, the four dimensional (4D) fluvial matrix and climatic causality. Geomorphology, 101, 278-297.

Brown, A. G. 2011. Aggregate-Related Archaeology in England in a changing environment, in A. G. Brown, L. S. Basell \& K. W. Butzer (Eds.) Geoarchaeology, Climate Change and Sustainability. Geological Society of America Special Publication,476, 183-194.

Brown, A. G., Basell, L. S. and Toms, P. T. 2014. A stacked Late Quaternary fluvio-periglacial sequence from the Axe valley, Southern England with implications for landscape evolution and Palaeolithic archaeology. Quaternary Science Reviews, 116, 1-16.

Brown, A. G., Basell, L. S., Robinson, S. and Burge, G. C. 2013a. Site Distribution at the Edge of the Palaeolithic World: A Nutritional Niche Approach. PLOS ONE, 8 (12), pp. 1-14. 
Brown, A. G., Toms, P, Carey, C. and Rhodes, E. 2013b. Geomorphology of the Anthropocene: timetrangressive discontinuities of human-induced alluviation. The Anthropocene, 1, 3-13.

Brown, A.G., Hatton, J., Pearson, L. Roseff, R. and Jackson, R. 2005. The Severn-Wye revisited: Lateglacial-Holocene floodplain palaeoenvironments in the Lugg Valley, in Smith, D.N., Brickley, M.B. \& Smith, W. (eds). Fertile Ground: Papers in Honour of Susan Limbrey. Symposia of the Association for Environmental Archaeology no 22. Oxbow Books: Oxford. 16-29.

Brown, A., Toms, P., Carey, C. J., Howard, A. and Challis, K. 2013c. Late Pleistocene and Holocene river dynamics at the Trent-Soar confluence, England, UK Earth Surface Processes and Landforms, 38, pp. 237-249.

Canti, M., Huisman, D. J. 2015. Scientific advances in geoarchaeology during the last twenty years. Journal of Archaeological Science, 56, 96 - 108.

Carey, C., Howard, A. J., Brown, A. G. and Challis, K. 2007. Approaches to archaeological geoprospection: recent work within the Trent valley, in T. S., White, D. R. Bridgland, A. J. Howard and M. J., White (Eds.). The Quaternary of the Trent Valley and Adjoining Regions: Field Guide. Quaternary Research Association, London. 66-71.

Castanet, C., Burnouf, J., Camertynck, C., Carcaud, N., Cyprien-Chouin, A.-L., Garcin, M., and Lamothe, M. 2014. Holocene fluvial dynamics of the middle Loire River (Val d'Orléans, France). Responses to climatic variability and anthropogenic impacts. Arnaud-Fassetta, G. and Carcaud, N. (Eds.) 2014. French Geoarchaeology in the 21st Century. CNRS Editions, Paris, 117-128.

Chapman, H., Adcock, J. and Gater, J. 2009. An approach to mapping buried prehistoric palaeosols of the Atlantic seaboard in Northwest Europe using GPS, geoarchaeology and GIS and the implications for heritage management. Journal of archaeological Science, 36, 2308-2313.

Chapman, H. 2006. Landscape archaeology and GIS. Stroud: Tempus.

Challis, K. and Howard, A. J. 2006. A review of trends within archaeological remote sensing in alluvial environments. Archaeological Prospection, 13, 231- 240.

Clark, A. 1990. Seeing beneath the soil. Prospecting methods in archaeology. Routledge: London. Conyers, L. B. 2004. Ground penetrating radar for archaeologists. California: Left Coast Press.

David, A., Linford, N. and Linford, P. 2008. Geophysical survey in archaeological field evaluation. Swindon: English Heritage.

Demján, P. and Dreslerová, D. 2016. Modelling distribution of archaeological settlement evidence based on heterogeneous spatial and temporal data. Journal of Archaeological Science, 69, 100-109.

Dinn, J. and Roseff, R. 1992. Alluvium and archaeology in the Herefordshire valleys, in Needham, S. \& Macklin, M.G. (eds). Alluvial Archaeology in Britian. Oxbow Monograph 27, Oxford. 141-154.

Duller, G. A. T. 2008. Luminescence Dating: Guidelines on Using Luminescence dating in Archaeology. English Heritage: Swindon. 
Ebert, D. 2006 'Predictive Modelling and Time: An Experiment in Temporal Archaeological Predictive Models'. Internet Archaeology, 20.

Espa, G., Beneditti, R., De Meo, A. and Espa, S. 2006. GIS based models and estimation methods for the probability of archaeological site detection. Journal of Cultural Heritage, 7, 147-155.

Fry, G. L. A., Skar, B., Jerpasen, G., Bakkestuen, V. and Erikstad, L. 2004. Locating archaeological sites in the landscape: a hierarchical approach based on landscape indicators. Landscape and Urban Planning, 67, $97-104$.

Gaffney, C. F. 2008. Detecting trends in prospecting for the past: fifty years of geophysical survey. Archaeometry, 50, 313-336.

Gaffney, C. and Gater, J. 2003. Revealing the buried past. Tempus: Stroud.

Gales, S.J. and Hoare, P.G. 2012. The stratigraphic status of the Anthropocene. The Holocene 22, 1478-1481.

Hermann, J. T. 2013. Three-dimensional mapping of archaeological and sedimentary deposits with ground penetrating radar at Saruq-al-Hadid, Dubai, United Arab Emirates. Archaeological Prospection, 20, $189-203$.

Hey, G. and Lacey, M. 2001. Evaluation of archaeological decision-making processes and sampling strategies. Kent County Council: Kent.

Hijmja, M. P., Cohen, K. M., Hoffmann, G., Van der Spek, A. J. F. and Stouthammer, E. 2009. From river valley to estuary: the evolution of the Rhine mouth in the early to middle Holocene (western Netherlands, Rhine-Meuse delta). Netherlands Journal of Geosciences, 88 (1), $13-53$.

Hoffmann, T., Thorndycraft, V.R., Brown, A.G., Coulthard, T. J, Damnati, B., Kale, V.S., Middelkoop, H., Notebaert, B., and Walling, D.E. 2010. Human impact on fluvial regimes and sediment flux during the Holocene: Review and future research agenda. Global and Planetary Change, 72, 87-98.

Howard, A. J., Kluiving S. J., Engel, M. and Heyvaert, M. A. 2015. Geoarchaeological records in temperate European river valleys: quantifying the resource, assessing its potential and managing its future. Quaternary International, 367, 42 - 50.

Howard, A. J., Brown, A. G., , Carey, C. J., Challis, K., Cooper, L., Kincey, M. and Toms, P. 2008 Archaeological resource modelling in temperate river valleys: a case study from the Trent Valley, UK Antiquity, 82 (318), 1040-1054.

Howard, A.J., Macklin, M.G., Passmore, D.G. (Eds). 2003. Alluvial Archaeology in Europe. Balkema: Abingdon.

Howard, A.J. and Macklin, M.G. 1999. A generic geomorphological approach to archaeological interpretation and prospection in British river valleys: a guide for archaeologists investigating Holocene landscapes. Antiquity, 73 (281), 527-541.

Jackson, R. and Miller, D. 2011. Wellington Quarry, Herefordshire (1986-96): Investigations of a Landscape in the Lower Lugg Valley. Oxbow Books, Oxford. 
Jackson, R, Brown, A G, Carey, C, Howard, A J, Mann, A, Roberts, A J, Sworn, S, and Toms, P S, 2013 Delivering the benefits of Aggregates Levy Sustainability Funded led research on river valley archaeological sites in the Severn-Wye catchment, UK. The Historic Environment. Policy and Practice, 3 (2), 97-115.

Jochim, M. 1976. Hunter-gatherer subsistence and settlement: a predictive model. Seminar: New York.

St Joseph, J. K. S. 1977. Uses of air photography. A \& C Black Publishers Ltd: New York.

Kamermans, H. 2010. The application of predictive modelling in archaeology problems and possibilities, in, F. Nicolucci and S. Hermon (eds.) Beyond the Artifact. Digital Interpretation of the Past. CAA 2004. BAR International Series 2494. Oxford: Archaeopress.

Kamerhams, H. and Wansleeben, M. 1999. Predictive modelling in Dutch archaeology, joining forces, in Juan A. Barcelo, Ivan Briz and Assumpció Vila (eds), New techniques for old times, CAA 98. BAR International Series 757. Oxford: Archaeopress.

Koster, K. 2016. Cone penetration testing: a sound method for urban archaeological prospection. Archaeological prospection, 25, pp. $55-69$.

Knight, D. and Howard, A. J. 2004. Trent Valley Landscapes. Heritage Marketing and Publications Ltd: Kings Lynn.

Lewin, J. and Macklin, M.G. 2014. Marking time in geomorphology: should we try to formalize an anthropocene definition? Earth Surface Processes and Landforms, 39 (1), 133-137.

Macklin, M. G., Passmore, D. G., Cowley, D. C., Stevenson, A. C., and O'Brien, C. F. 1992. Geoarchaeological enhancement of river valley archaeology in North East England, in P Spoerry (ed), Geoprospection in the archaeological landscape. Oxbow Monograph No 18, 43-58. Oxbow: Oxford.

Marchetti, M. 2002. Environmental changes in the central Po Plain (northern Italy) due to fluvial modifications and anthropogenic activities. Geomorphology, 44, 361-373.

Mozzi, P. 2012. The rivers of Padua: geoarchaeological investigation of a fluvial city. Quaternary International, 341, 279-280.

Neal, C. 2014. The potential of integrated urban deposit modelling as a cultural heritage planning tool. Planning, Practice and Research, 93 (3), 256-257.

Ninfo, A., Fontana, A., Mozzi, P. and Ferrarese 2009. The Map of Altinum, Ancestor of Venice. Science, 325, 577.

Passmore, D.G. and Waddington, C. 2009. Managing archaeological landscapes in Northumberland. Till-Tweed Studies, Volume 1. Oxbow Books, Oxford.

Passmore, D.G., Waddington, C. and van der Schriek, T., 2006. Enhancing the evaluation and management of river valley archaeology: geoarchaeology, in the Till-Tweed catchment, northern England. Archaeological Prospection, 13, 269-281. 
Passmore, D. G., Waddington, C. and Houghton, S. J. 2002. Geoarchaeology of the Millfield basin, Norther England; towards an integrated archaeological prospection, research and management framework. Archaeological Prospection, 9, $71-91$.

Parcak, S. H. 2009. Satellite Remote Sensing for Archaeology. Routledge: Oxford.

Pastre, J.-F., Leroyer, C., Limondin-Lozouet, P., Antoine, P., Chaussé, C., Gauthier, A., Granai, S., Le Jeune, Y., and Wuscher, P. 2014. The Holocene evolution of the Patis Basin (France). Contribution of geoecology and geoarchaeology of floodplains, in Arnaud-Fassetta, G. and Carcaud, N. (Eds.) 2014. French Geoarchaeology in the 21st Century. CNRS Editions, Paris, 87-104.

Rua, H. 2009. Geographic information systems in archaeological analysis: a predictive model in the detection of rural Roman villae. Journal of Archaeological Science, 36, 224 - 235.

Rowlands, A. and Sarris, A. 2007. Detection of exposed and subsurface archaeological remains using multi-sensor remote sensing. Journal of Archaeological Science, 34, 795-803.

Sidell, J. Wilkinson, K., Scaife, R. and Cameron, N. 2000. The Holocene Evolution of the London Thames. Museum of London Archaeology Monograph 5, London.

Smith, D. N., Roseff, R., Bevan, L., Brown, A. G., Butler, S., Hughes, G. and Monkton, A. 2005 Archaeological and environmental investigations of Late Glacial and Holocene river valley sequences on the River Soar, at Croft, Leicestershire. The Holocene, 15, 353-377.

Toms, P.S., Brown, A.G., Jackson, R. and Mann, A. 2011. Piloting Optical dating of terraces in the Lower Severn Valley. English Heritage Research Department Report, 36-2011.

Törnquist, T. E. 1994. Middle and Late Holocene avulsion history of the River Rhine (Rhine-Meuse delta, Netherlands). Geology, 22, $711-714$.

Van De Wiel, M.J., Coulthard, T.J., Macklin, M.G.and Lewin, J. 2011. Modelling the response of river systems to environmental change: Progress, problems and prospects for palaeoenvironmental reconstructions. Earth-Science Reviews, 103, 167-185.

Vaughn, S. and Crawford, T. 2009. A predictive model of archaeological potential: an example from northwestern Belize. Applied Geography, 29, 542 - 555.

Verhagge, J., Missiaen, T. and Crombe, P. 2016. Exploring integrated geophysics and geotechnics as a palaeolandscape reconstruction tool: archaeological prospection of (prehistoric) sites buried deeply below the Scheldt Polders (NW Belgium). Archaeological prospection, 23.

Verhagen, P., Rensink, E., Bats, M. and Crombé, P. 2013 Establishing discovery probabilities of lithic artefacts in Palaeolithic and Mesolithic sites with core sampling. Journal of Archaeological Science, 40 (1), 240-247.

Verhagen, P. and Drăguţ, P. 2012. Object-based landform delineation and classification from DEMs for archaeological predictive mapping. Journal of Archaeological Science, 39, 698- 703.

Verhagen, P. and Whitley, T. G. 2012. Integrating archaeological theory and predictive modelling: a live report from the scene. Journal of Archaeological Method and Theory, 19, $49-100$. 
Verhagen, P. and Borsboom, A. 2009. The design of effective and efficient trial trenching strategies for discovering archaeological sites. Journal of Archaeological Science, 36, 1807 - 1815.

Verhagen, P. and Tol, A. 2004. Establishing optimal core sampling strategies: theory, simulation and practical implications, in A. Fischer Ausserer, W. Börner, M. Goriany and L. Karlhuber-Vöckl (eds.), Enter the Past. The E-way into the four Dimensions of Cultural Heritage. CAA 2003. Computer Applications and Quantitative Methods in Archaeology (BAR International Series 1227). Archaeopress, Oxford, pp. 416-419. 


\begin{tabular}{|c|c|c|c|c|c|c|}
\hline $\begin{array}{l}\text { Geomorphological } \\
\text { unit }\end{array}$ & $\begin{array}{l}\text { Depth of } \\
\text { historic } \\
\text { alluvium BGL } \\
\text { (sediment unit } \\
\text { 1) }\end{array}$ & $\begin{array}{l}\text { Depth of } \\
\text { prehistoric } \\
\text { alluvium BGL } \\
\text { (sediment unit } \\
\text { 2) }\end{array}$ & $\begin{array}{l}\text { Depth of palaeochannel fill } \\
\text { (BGL) }\end{array}$ & Predicted age & $\begin{array}{l}\text { Archaeological } \\
\text { potential }\end{array}$ & $\begin{array}{l}\text { Palaeo- } \\
\text { environmental } \\
\text { potential }\end{array}$ \\
\hline Terrace unit $\mathrm{H} 2$ & $0.5 \mathrm{~m}$ & $\begin{array}{l}0.5 m-1.1 m \\
B G L\end{array}$ & - & Devensian & High & $\begin{array}{l}\text { Low, except with in } \\
\text { feature fills }\end{array}$ \\
\hline Terrace unit $\mathrm{H} 1$ & $0.4 \mathrm{~m} \mathrm{BGL}$ & $0.4-1.1 \mathrm{~m} \mathrm{BGL}$ & - & $\begin{array}{l}\text { Devensian with late } \\
\text { Pleistocene/Early } \\
\text { Holocene erosion }\end{array}$ & Low to Moderate & Low \\
\hline Palaeochannel 1 & - & - & $\begin{array}{l}1.8 \mathrm{~m}, \text { Organic basal fill, } \\
\text { minerogenic upper fill }\end{array}$ & $\begin{array}{l}\text { Undefined - Mid } \\
\text { Holocene? }\end{array}$ & Moderate & High \\
\hline Palaeochannel 2 & - & - & $\begin{array}{l}\text { 2.0m Minerogenic lower fill, } \\
\text { organic upper fill }\end{array}$ & $\begin{array}{l}\text { Undefined before } \\
\text { trenching }\end{array}$ & $\begin{array}{l}\text { Moderate, although } \\
\text { potentially erosive }\end{array}$ & High \\
\hline Palaeochannel 3 & - & - & $\begin{array}{l}\text { 2.0m Minerogenic sand/silt } \\
\text { dominated throughout fill } \\
\text { sequence }\end{array}$ & Early Holocene & Low & Low \\
\hline $\begin{array}{l}\text { Palaeochannel } 4 \\
\text { (subsequently } \\
\text { outside the } \\
\text { development area) }\end{array}$ & & & $\begin{array}{l}0.8 \mathrm{~m} \text { Minerogenic, sand } \\
\text { and silt dominated }\end{array}$ & $\begin{array}{l}\text { Later Holocene, } \\
\text { Medieval - Post } \\
\text { Medieval (no } \\
\text { absolute dates) }\end{array}$ & Low & Low \\
\hline
\end{tabular}

Table 1: Geoarchaeological deposit model of archaeological and palaeoenvironmental potential across the development area, before application of radiocarbon dates from excavated deposits. 


\begin{tabular}{|c|c|c|c|c|c|c|}
\hline Sample & Material & Rationale and predicted age & Lab. code & ? ${ }^{13} \mathrm{C} \%$ o & $\begin{array}{l}\text { Radiocarbon } \\
\text { age BP }\end{array}$ & OxCal calibrated age (2sigma) \\
\hline $\begin{array}{l}\text { Context } 2715 \\
\text { Trench } 27\end{array}$ & $\begin{array}{l}\text { Charred } \\
\text { Hazelnut }\end{array}$ & $\begin{array}{l}\text { Refine dating of Neolithic pit from } \\
\text { lower fill, cutting unit } 2 \text {. Anticipated } \\
\text { date } 3700-3400 B C\end{array}$ & $\begin{array}{l}\text { Beta - } \\
245652\end{array}$ & $-23.7 \%$ & $4730+/-40 \mathrm{BP}$ & $\begin{array}{l}\text { Cal BC } 3640 \text { to } 3490 \text { (Cal BP } 5590 \text { to } 5440 \text { ) \& } \\
\text { Cal BC } 3460 \text { to } 3370 \text { (Cal BP } 5420 \text { to } 5320 \text { ) }\end{array}$ \\
\hline $\begin{array}{l}\text { Context } 1503 \\
\text { Trench } 15\end{array}$ & $\begin{array}{l}\text { Charred } \\
\text { Hazelnut twig }\end{array}$ & $\begin{array}{l}\text { Ditch fill to date ditch early within } \\
\text { alluvial sequence. Anticipated early } \\
\text { Neolithic date (or earlier) }\end{array}$ & $\begin{array}{l}\text { Beta - } \\
245653\end{array}$ & $-24.1 \%$ & $4960+/-40$ BP & $\begin{array}{l}\text { Cal BC } 3900 \text { to } 3880 \text { (Cal BP } 5850 \text { to } 5840 \text { ) \& } \\
\text { Cal BC } 3800 \text { to } 3650 \text { (Cal BP } 5750 \text { to } 5600 \text { ) }\end{array}$ \\
\hline $\begin{array}{l}\text { Context } 1404 \\
\text { Trench } 14\end{array}$ & $\begin{array}{l}\text { Charred } \\
\text { Hazelnut }\end{array}$ & $\begin{array}{l}\text { Refine dating of Bronze Age } \\
\text { cremation cemetery, cutting unit } 2 . \\
\text { Anticipated date } 1750-1250 \mathrm{BC}\end{array}$ & $\begin{array}{l}\text { Beta - } \\
245654\end{array}$ & $-27.0 \%$ & $3000+/-40 \mathrm{BP}$ & Cal BC 1380 to 1120 (Cal BP 3330 to 3070 ) \\
\hline $\begin{array}{l}\text { Context } 2902 \\
\text { Trench } 29\end{array}$ & $\begin{array}{l}\text { Decayed } \\
\text { humic } \\
\text { material (Unit } \\
\text { 5) }\end{array}$ & $\begin{array}{l}\text { Establish dating of early stasis event } \\
\text { in alluvial sequence (Unit 5). A dark } \\
\text { brown black silty clay, within } \\
\text { palaeochannel } 3 \text { sequence. }\end{array}$ & $\begin{array}{l}\text { Beta - } \\
245655\end{array}$ & $-25.6 \%$ & $9520+/-60 \mathrm{BP}$ & $\begin{array}{l}\text { Cal BC } 9150 \text { to } 8700 \text { (Cal BP } 11100 \text { to } 10650) \\
\text { AND Cal BC } 8680 \text { to } 8650 \text { (Cal BP } 10620 \text { to } \\
\text { 10600) }\end{array}$ \\
\hline $\begin{array}{l}\text { Context } 3802 \\
\text { Trench } 38\end{array}$ & & $\begin{array}{l}\text { Establish dating of extensive peat } \\
\text { horizon between units } 2 \text { and } 3 \text { on } \\
\text { terrace } \mathrm{H} 1 \text {. Anticipated early } \\
\text { medieval date. }\end{array}$ & $\begin{array}{l}\text { Beta - } \\
245656\end{array}$ & $-26.7 \%$ & $1040+/-40 \mathrm{BP}$ & $\begin{array}{l}\text { Cal AD } 900 \text { to } 920 \text { (Cal BP } 1050 \text { to 1030) AND } \\
\text { Cal AD } 950 \text { to } 1040 \text { (Cal BP } 1000 \text { to } 920)\end{array}$ \\
\hline $\begin{array}{l}\text { Context } 2812 \\
\text { Trench } 28\end{array}$ & Elm sp. wood & $\begin{array}{l}\text { Establish date of phase } 1 \mathrm{i} \text { of } \\
\text { Palaeochannel } 1\end{array}$ & $\begin{array}{l}\text { Beta - } \\
245659\end{array}$ & $-26.8 \%$ & $5770+/-40 \mathrm{BP}$ & Cal BC 4720 to 4520 (Cal BP 6660 to 6470 ) \\
\hline $\begin{array}{l}\text { Context } 2810 \\
\text { Trench } 28 \\
0-10 \mathrm{~cm}\end{array}$ & $\begin{array}{l}\text { Yellow Iris } \\
\text { seed }\end{array}$ & $\begin{array}{l}\text { Establish "closure" date of the phase } \\
\text { 1iii of Palaeochannel } 1\end{array}$ & $\begin{array}{l}\text { Beta - } \\
245660\end{array}$ & $-25.8 \%$ & $790+/-40 \mathrm{BP}$ & Cal AD 1170 to 1280 (Cal BP 780 to 670 ) \\
\hline $\begin{array}{l}\text { Context } 2810 \\
\text { Trench } 28 \\
20-30 \mathrm{~cm}\end{array}$ & $\begin{array}{l}\text { Club Rush } \\
\text { seed }\end{array}$ & $\begin{array}{l}\text { Establish date of phase 1iii of } \\
\text { Palaeochannel } 1\end{array}$ & $\begin{array}{l}\text { Beta - } \\
245661\end{array}$ & $-24.0 \%$ & $1210+/-40 \mathrm{BP}$ & Cal AD 690 to 900 (Cal BP 1260 to 1050) \\
\hline
\end{tabular}

Table 2: Summary results of radiocarbon dating programme, from samples recovered during evaluation excavation. 


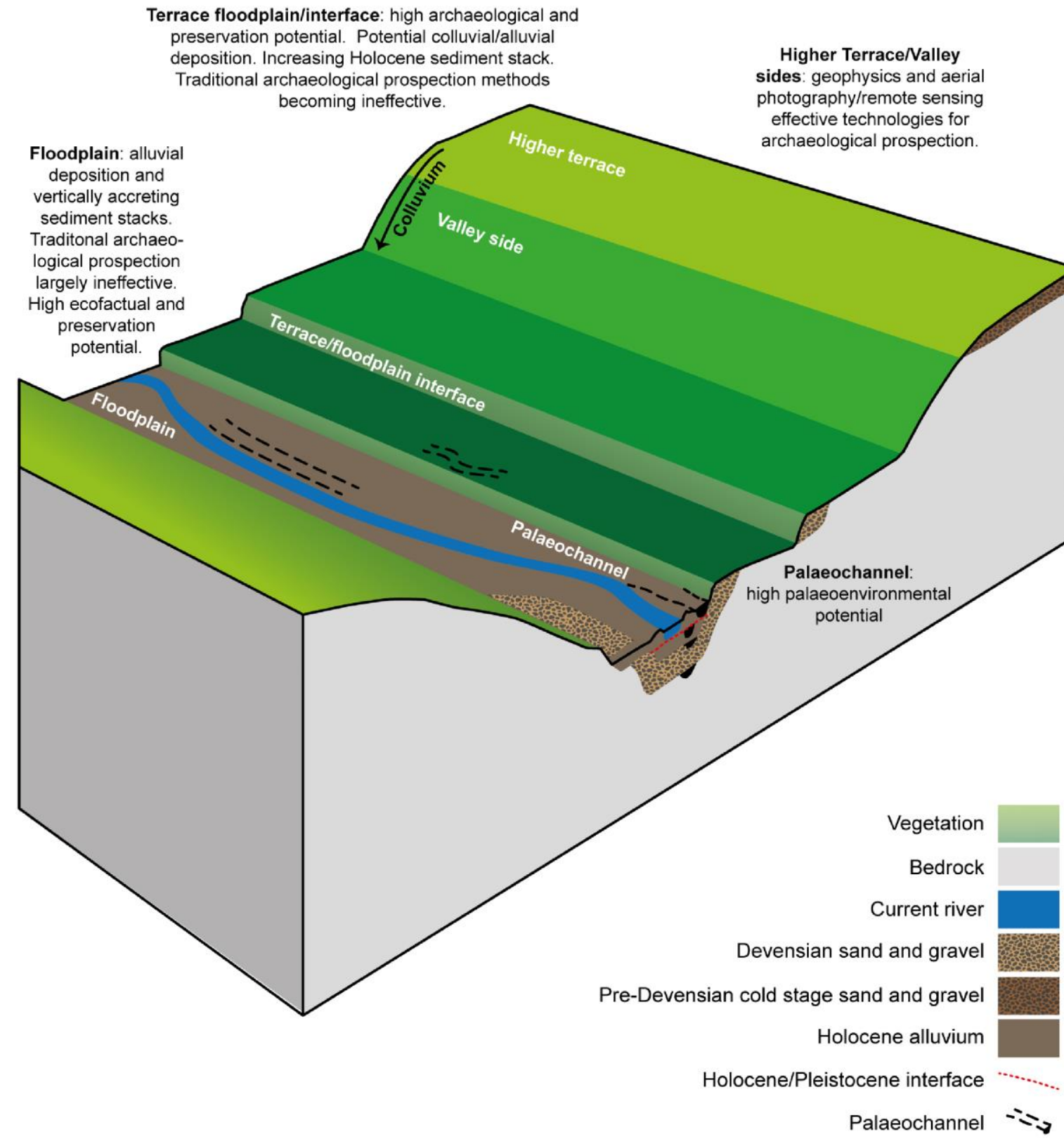

Figure 1: Idealised cross section of a temperate river valley, highlighting key geomorphological and archaeological prospection issues 

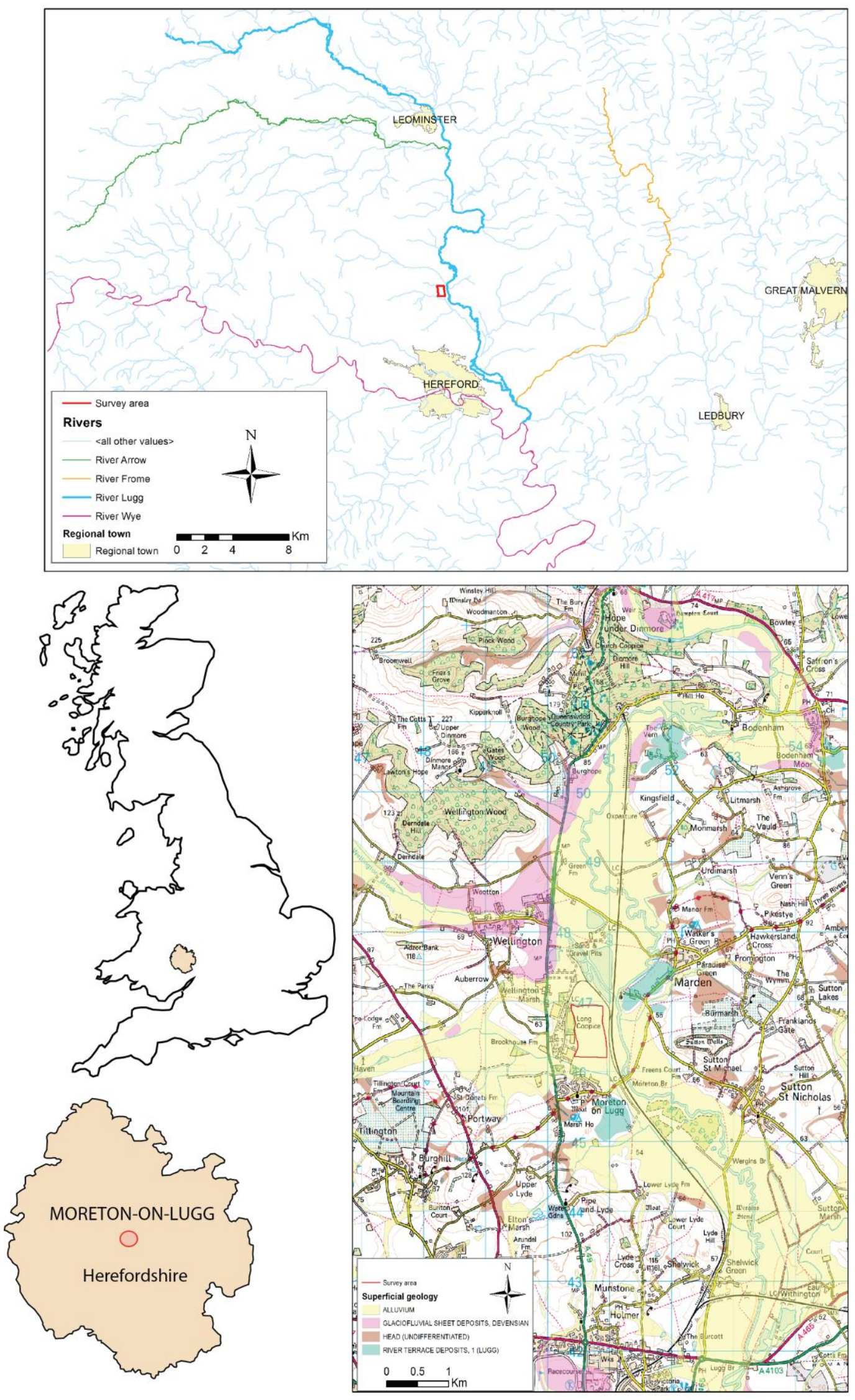

Figure 2: The location of the study area on national and regional scales. 


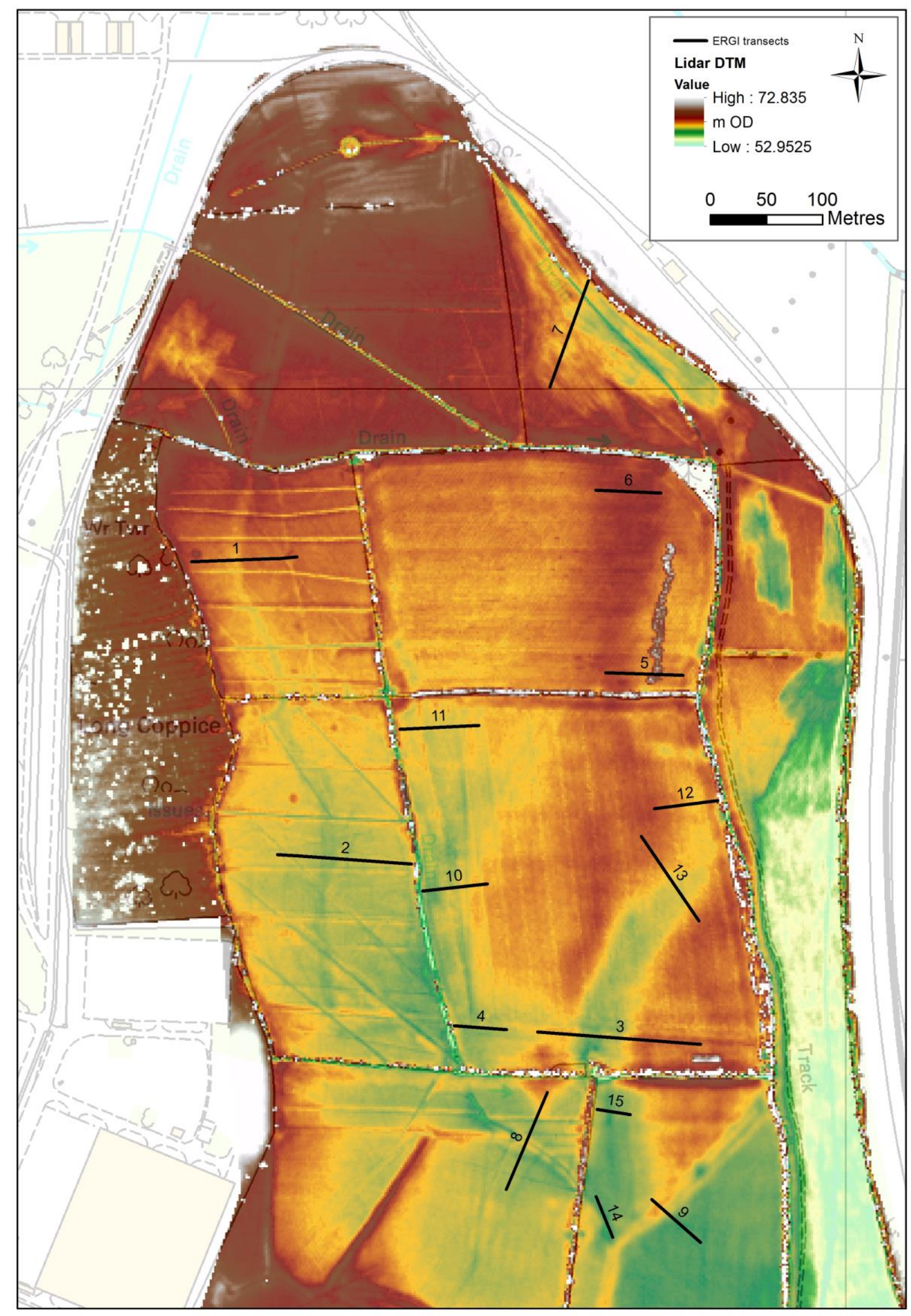

Figure 3: The lidar DTM for the study area with electrical resistivity transect locations. 


\section{Transect 3}

A) Electrical resistivity section with gouge core transect

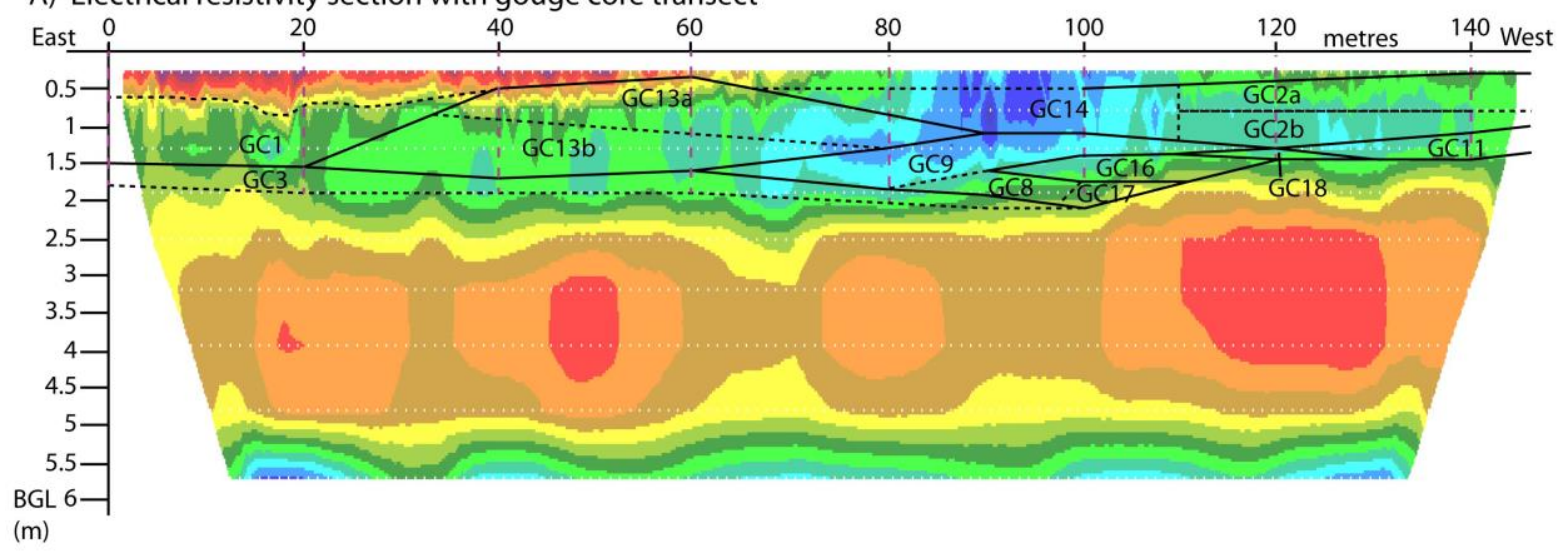

B) Electrical resistivity section with interpretation

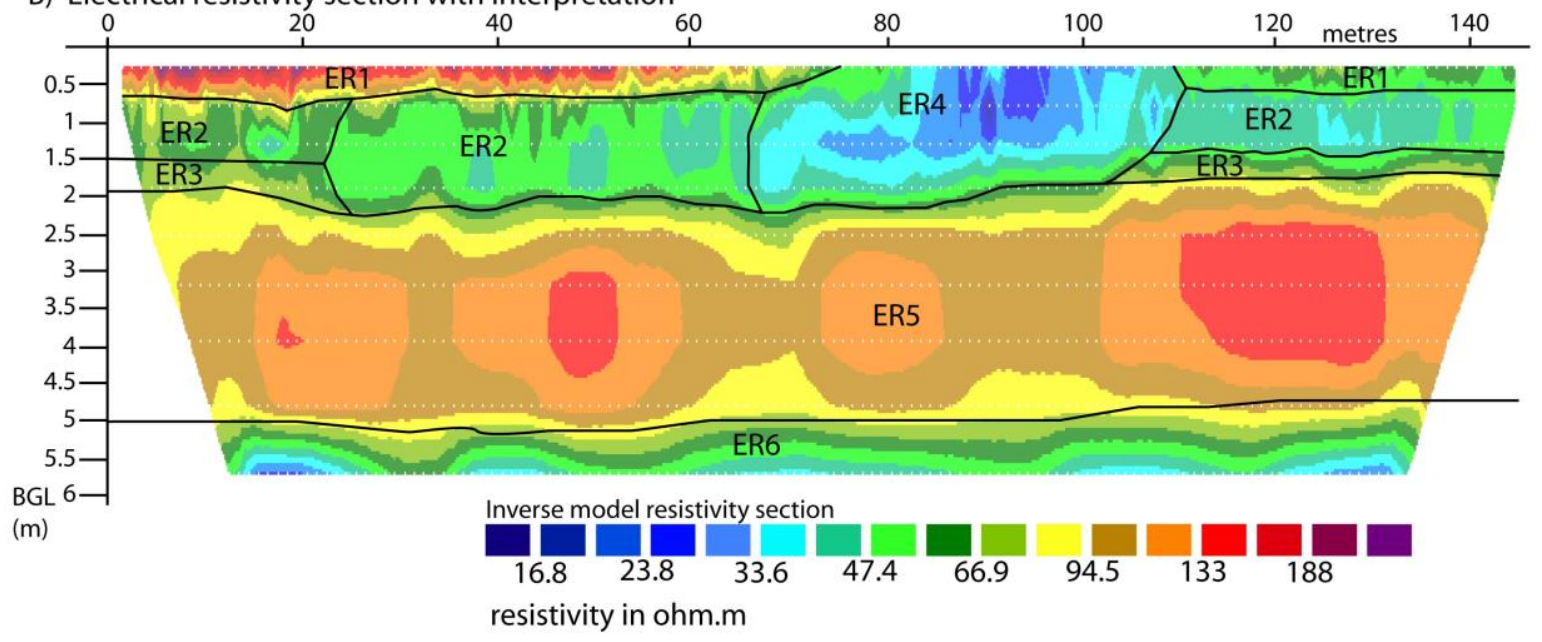

GC1 = Red brown silty clay (unit 1).

GC2a = Yellow grey clayey silt (unit 2).

ERGI interpretation stratigraphy:

$\mathrm{GC} 2 \mathrm{~b}=$ Yellow grey silty clay (unit 2).

$\mathrm{ER} 1=$ Terrace alluvium (high resistivity) $=$ Unit 1

GC3 = Sand and gravel in red clay matrix (unit 3).

$\mathrm{ER} 2=$ Terrace alluvium (low-medium resistivity) $=$ Unit 2

$\mathrm{GC} 8$ = Blue grey clayey silt with organic matter.

ER3 - Medium resistivity unit, clay/gravel interface

$\mathrm{GC9}=$ Blue grey silty clay with organic matter.

ER4 $=$ Palaeochannel

$\mathrm{GC11}=$ Red grey clay .

$\mathrm{ER} 5=$ Sand and gravel

$\mathrm{GC13a}=$ Light brown clayey silt.

$\mathrm{GC} 13 \mathrm{~b}=$ Light brown silty clay.

$\mathrm{ER} 6=$ Bedrock

$\mathrm{GC14}=$ Red brown clayey silt.

- Interpreted sediment boundary

GC16 $=$ Blue grey clay .

-. - Gouge core location

GC17 = Light grey clayey silt with organics.

$\mathrm{GC18}=$ Grey brown gravelly, silty sand.

Figure 4: Electrical resistivity transect interpretation and gouge core data of transect 3. 
Schematic interpretation of the sediment units across transect 3.

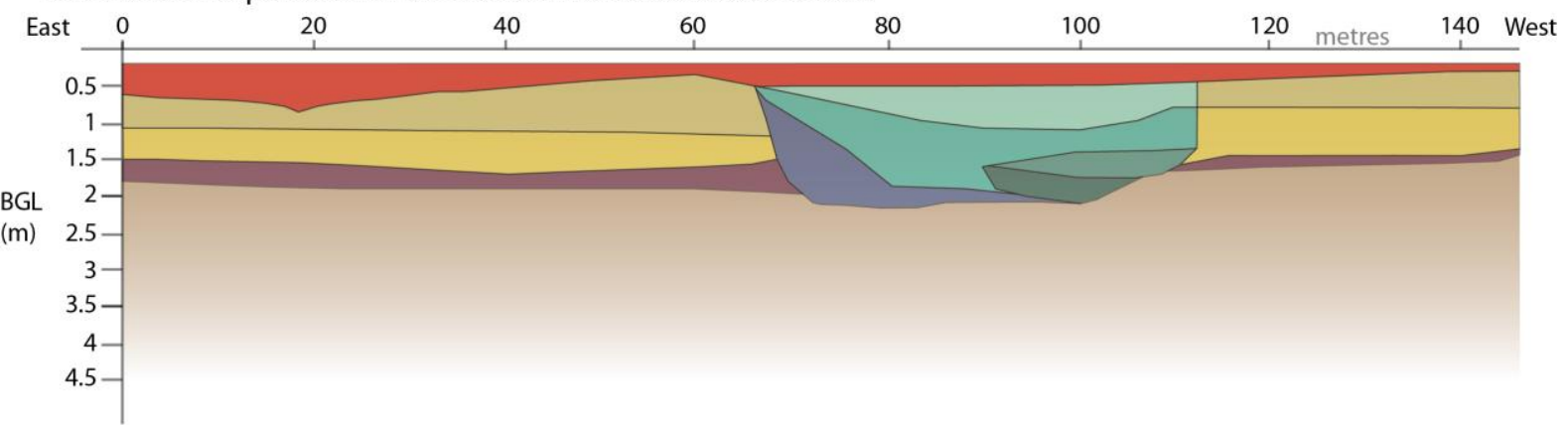

Key sediment units

Unit 1 - Red brown silty clay

Unit 2a - Upper yellow brown clayey silt

Unit 2b-Lower yellow brown clayey silt

Unit 3-Red brown silty clay witth clasts

Sand and Gravel
Palaeochannel fill sequence

Fill 1 - Reddy brown clayey silt

Fill 2 - Blue grey silty clay with organics

Fill 3 - Blue grey silty clay

Fill 4 - Light grey clayey silt with organics

Fill 5 - Blue grey silty clay with organics

Figure 5: Schematic interpretation of electrical resistivity transect 3. 


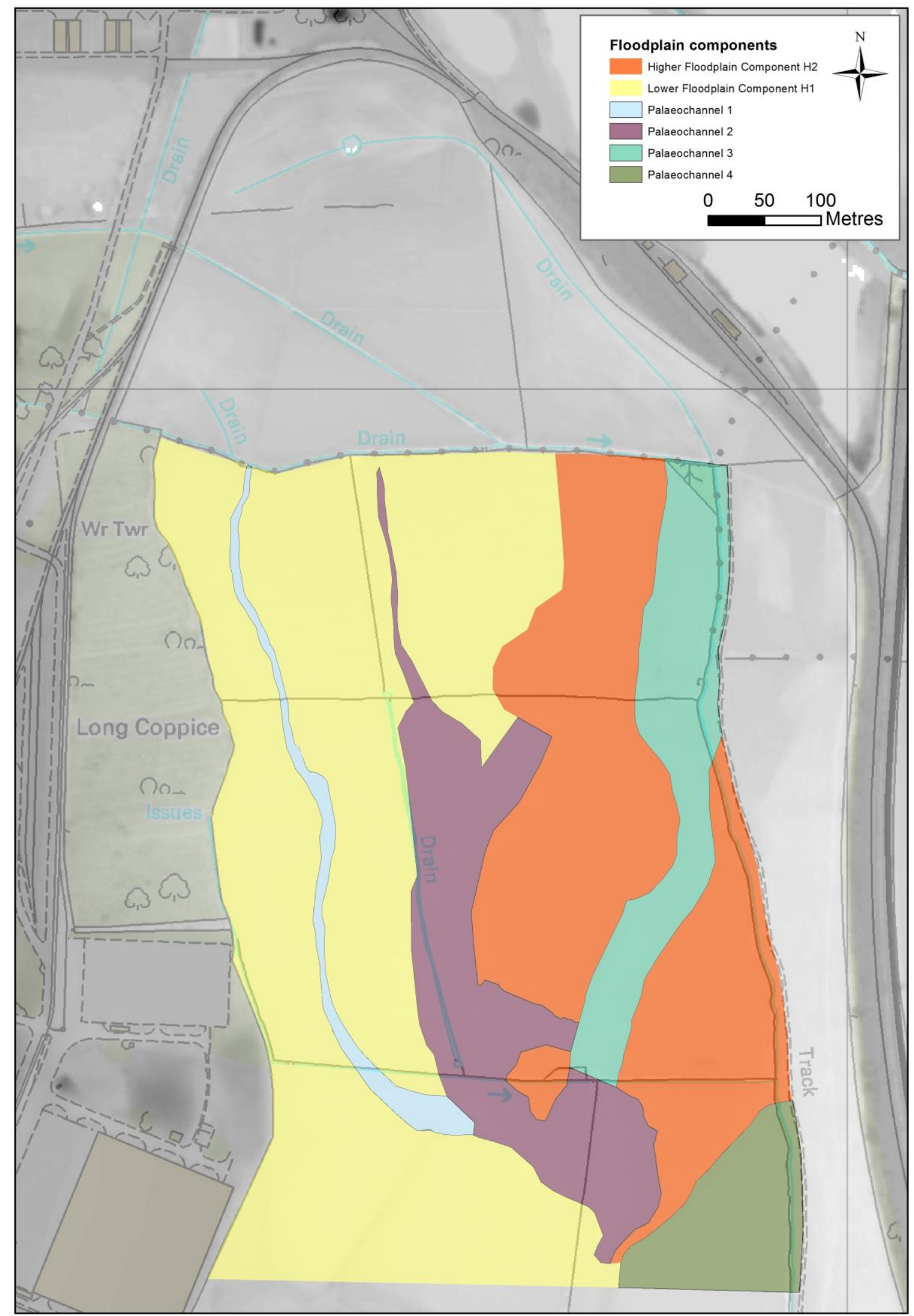

Figure 6: The key geomorphological floodplain components providing the basis of the predictive model for the study area. 


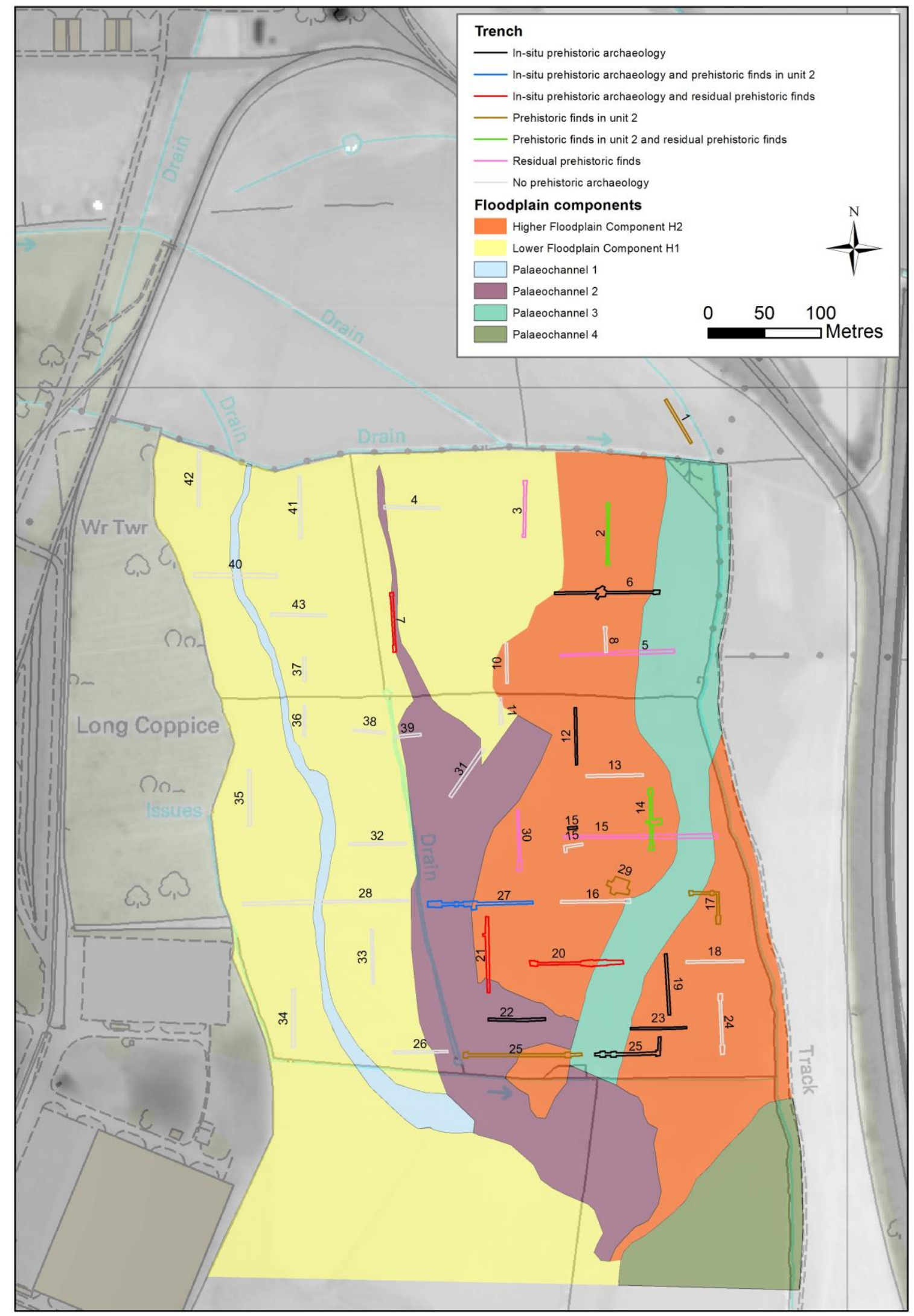

Figure 7: The distribution of In-situ features, stratified finds and residual finds of prehistoric archaeology across the study area as defined by the evaluation trenching. 


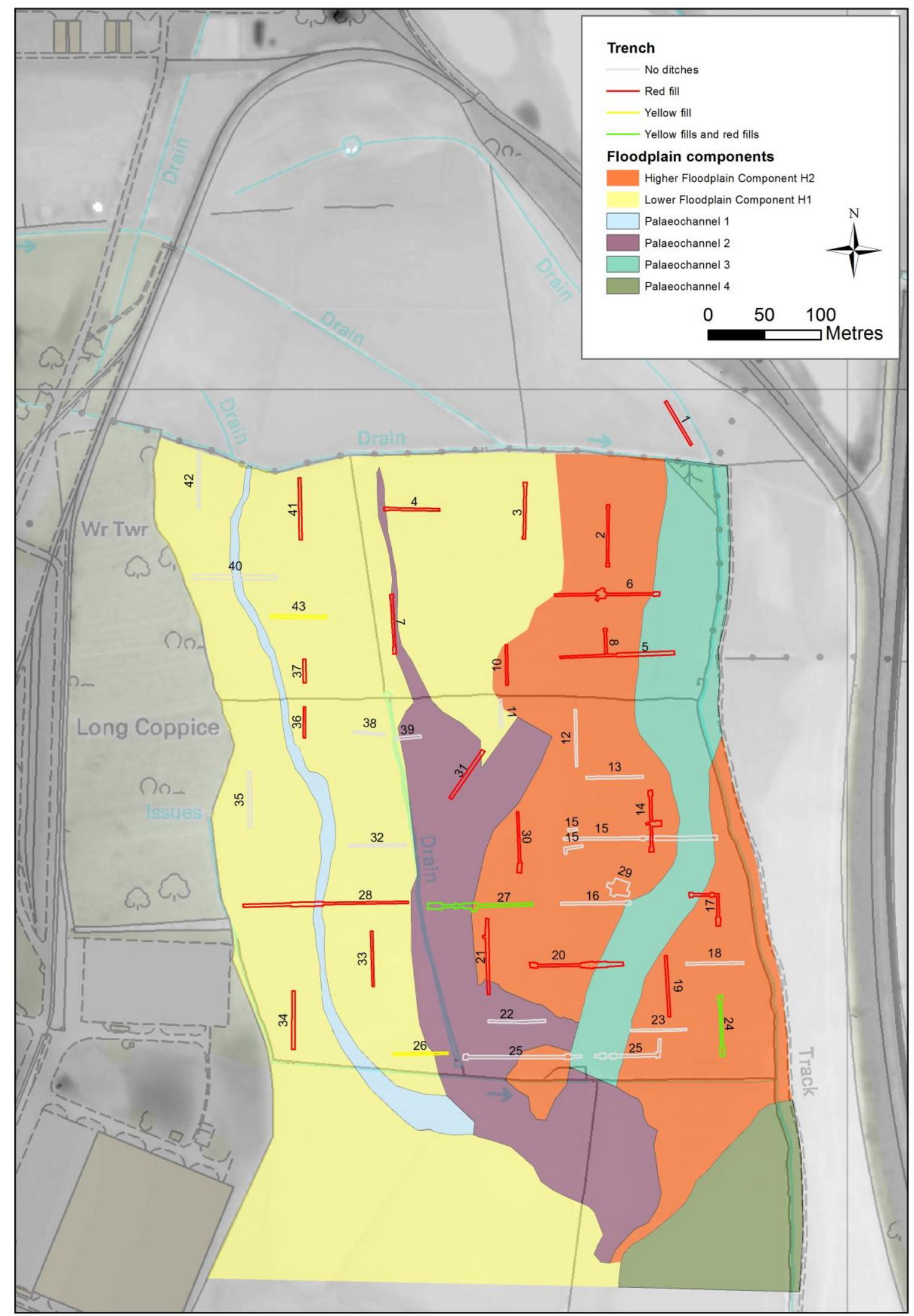

Figure 8: Ditches with yellow coloured fill sequences and red coloured fill sequences across the study area as defined by the evaluation trenching. 


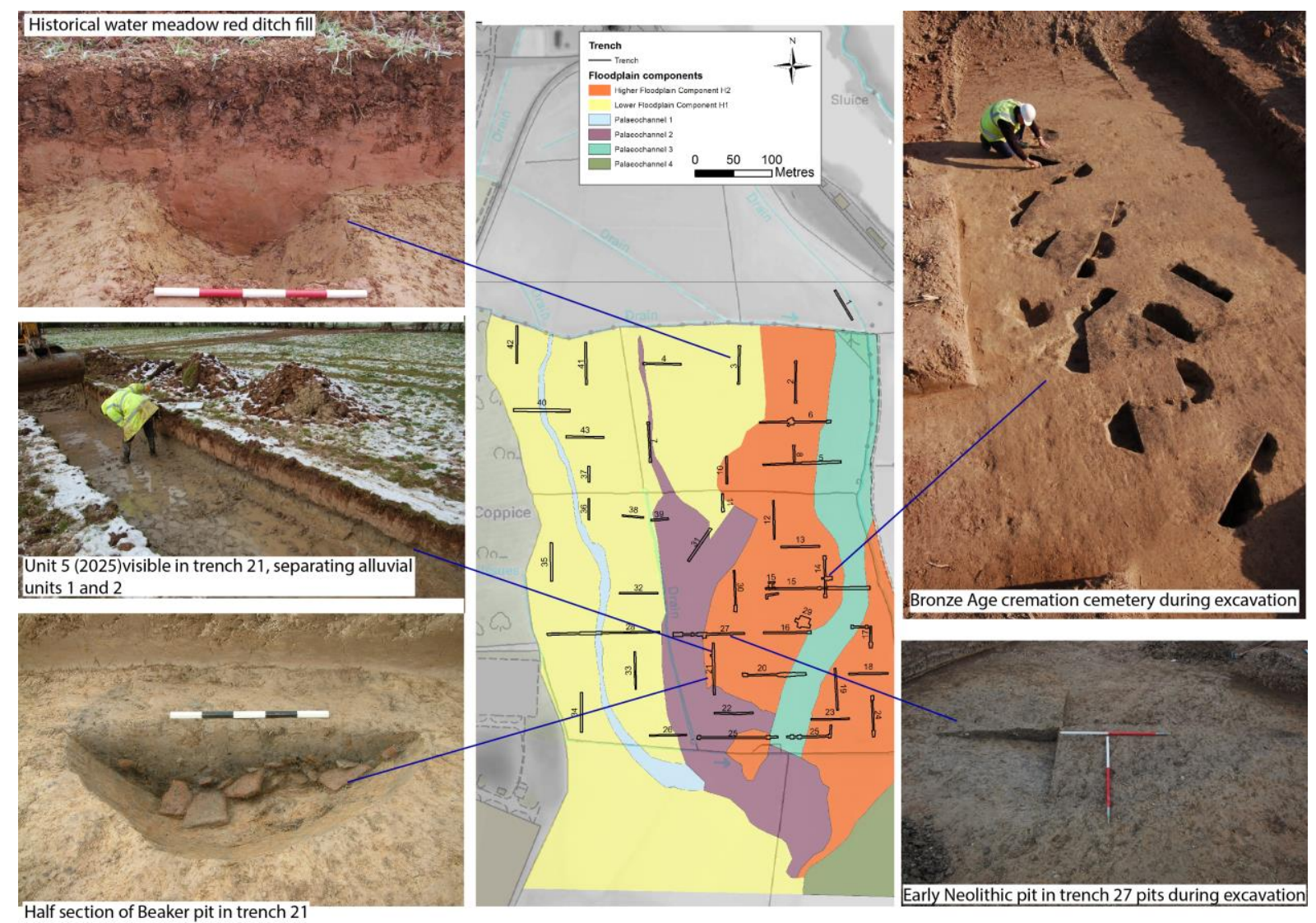

Figure 9: Archaeological and geoarchaeological 'highlights' in the evaluation area. 


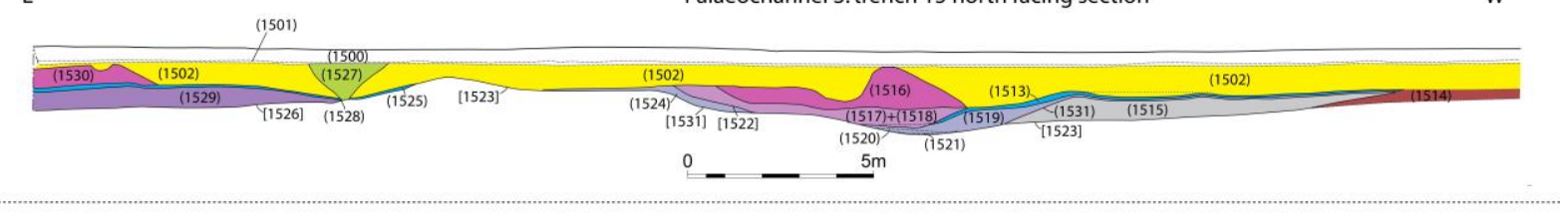

w

Palaeochannel 2: trench 26 south facing section
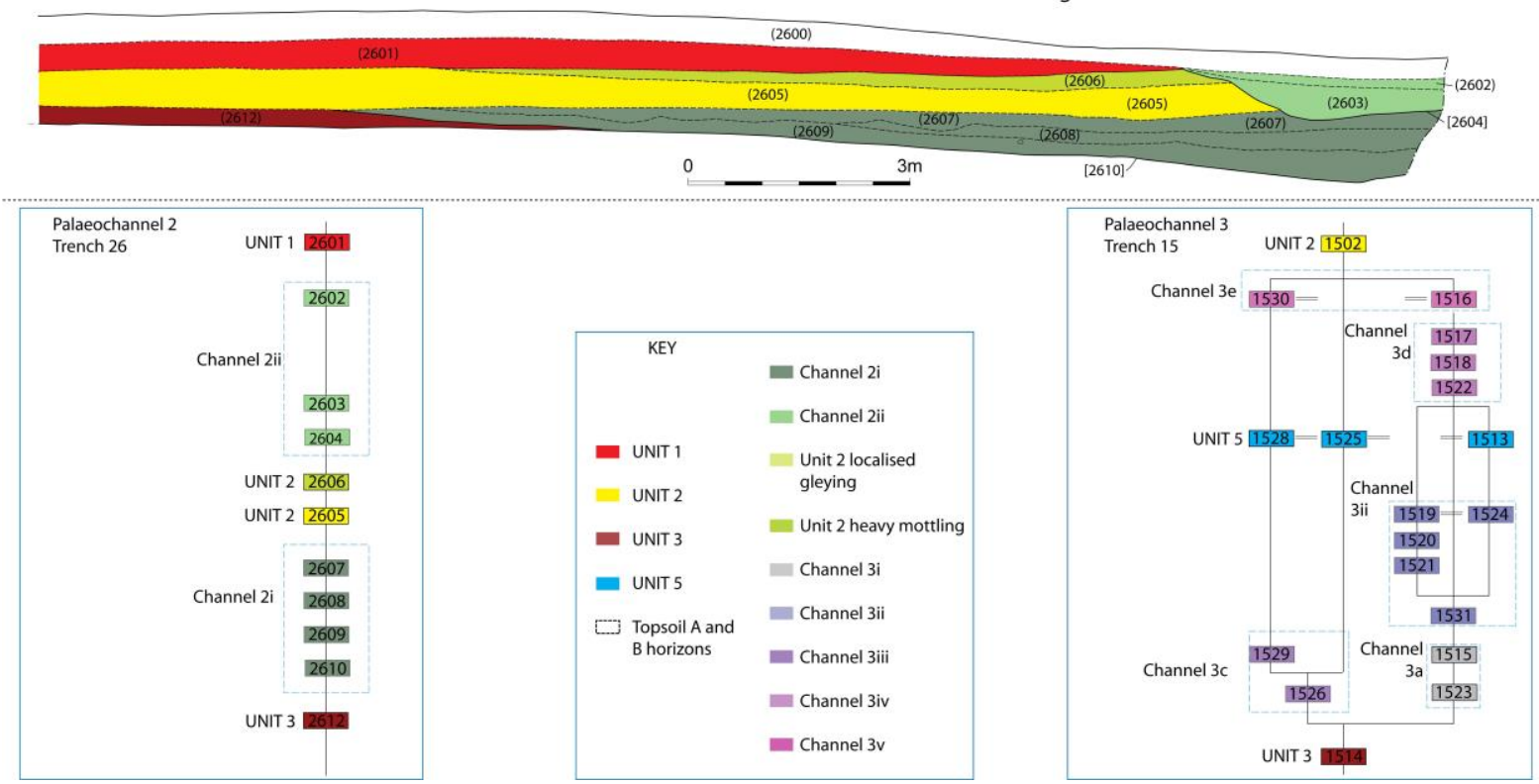

Figure 10: Sections of palaeochannels 2 and 3 showing multiple reactivations and relationships to the main alluvial stratigraphic units. 


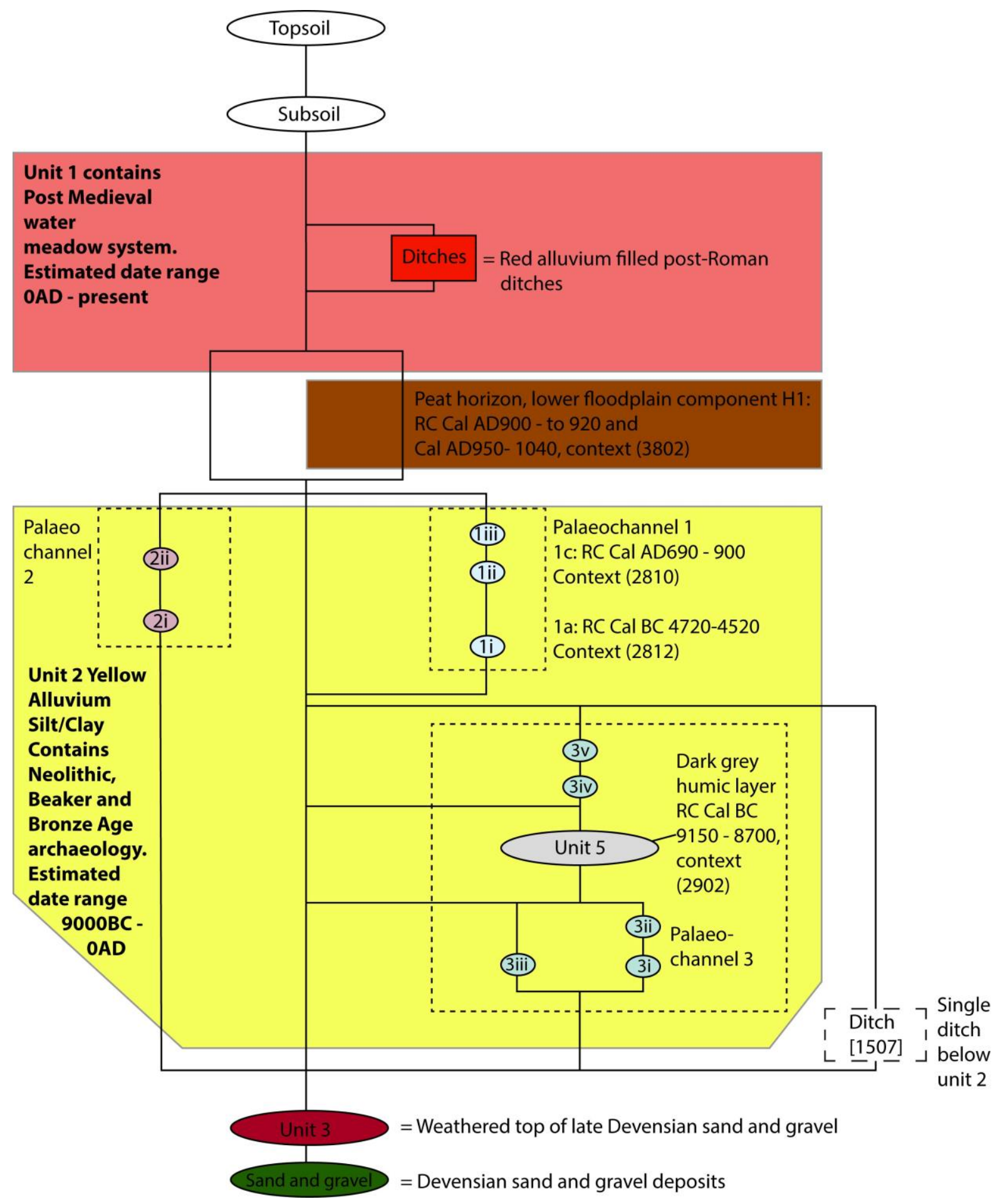

Figure 11: Overall schematic stratigraphic matrix of major alluvial and archaeological phases. 